\title{
Factors Influencing the Purchase of Counterfeit Drugs among Consumers in Rural Community of Cross River State, Nigeria
}

\author{
Article by Agada Peter Okpe ${ }^{1}$, Okareh Oladapo Okareh ${ }^{2}$, Ugobo Emmanuel Eteng ${ }^{3}$ \\ ${ }^{1}$ Senior Pharmacy Specialist, Howard University PACE Center (HU PACE), Strengthening \\ Integrated Delivery of HIV/AIDS Services (SIDHAS) project, Cross River State Office, \\ Calabar, Cross River State, Nigeria \\ ${ }^{2}$ Senoir Lecturer, Dept. of EHS, Faculty of Public Health, College of Medicine, University of \\ Ibadan, Ibadan, Nigeria \\ ${ }^{3}$ Howard University PACE Center (HU PACE), Strengthening Integrated Delivery of \\ HIV/AIDS Services (SIDHAS) project, Cross River State Office, Calabar, Cross River State, \\ Nigeria

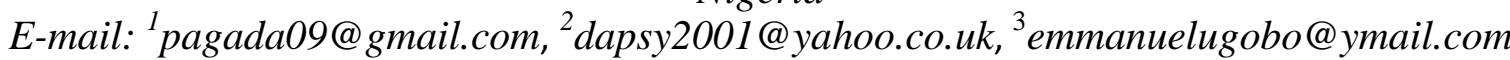

\begin{abstract}
Background: The purchase of counterfeit drugs by consumers is a serious public health problem and there are no sufficient researches dedicated to understanding the problem of drug counterfeiting from the consumers' perspective.

Aim: The aim of this study to assess factors influencing the purchase of counterfeit drugs among consumers in rural community using the concept of planned behavior (TPB) as a guide.

Methodology: This study is a cross-sectional descriptive research, using pretested questionnaire for data collection to ensure validity and reliability of instrument. A sample size of 236 was used for this study. Data was analyzed using SPSS version 20.0.

Results: The respondents mean age is 30.51years $(S D=11.46)$. Findings from this study showed that 139(58.9\%) of the respondents were males while 97(41.1\%) were females. Majority of the respondents 56(23.7\%) reported the cost of the drug as frequently used means of identification of counterfeit drugs in the community. Respondents perceived associated risk of counterfeit drugs includes: unexpected side effects 33(14\%), allergic reactions 38(16.1\%), worsening of their medical condition 48(20.3\%), death 46(19.5\%) and overdose 19(8.1\%). Findings from this study also showed a correlation between behavioural intention and attitude $(R=0.64)$. Subjective norms were associated with behavioural intention $(R=0.65)$ but was not significant at 0.005 . There was also an observed significant relationship between behavioural intentions and motivation $(R=0.52)$.

Conclusion: Drug consumers mainly use cost of drugs as a means of identification of counterfeit drugs. Consumers behavior, intention and attitude towards counterfeit drugs are correlated.
\end{abstract}

Keywords: counterfeit drugs, consumers perspectives, planned behavior.

\section{Introduction}

The availability of counterfeit drugs in the market presents a serious public health problem, particularly in developing countries such as Nigeria, and may have a significant impact on the national disease and economic burden. In 2002, the World Health Organization reported that 70 percent of drugs in Nigeria were fake or substandard; the National Agency for Food and Drug Administration and Control (NAFDAC) estimated that 41 percent of drugs alone were counterfeit $(1,2)$. Estimate suggests that $10 \%$ of prescription drugs sold worldwide are counterfeits, fake or contaminated, and in parts of Africa and Asia, the figures exceed 50\%(3)

Counterfeit medicines are widespread and represent a threat to public health which can lead to healthcare failures, such as resistance to antibiotics and the spread of disease within a community, as well as loss of life. Research has also shown that poor-quality medicines can reach the market through 
deliberate fraudulent practices by those that want to get rich overnight. There is low awareness of the problem of counterfeit medicine; a problem that could lead to public-health crisis (4). Knowledge, attitude and practice regarding counterfeit drugs are often undermine and given less concern in the area of research.

Measuring the magnitude of the phenomenon of counterfeit drugs turns out to be extremely complicated, particularly due to various reasons that have to do with the disposable means to detect the trafficking routes, the number and the identity of those involved in the production and distribution processes, and the difficulty in systematizing and coordinating the information from the various stakeholders in charge of keeping, collecting and analyzing data (4).

Available statistics have tried to propose figures on the exact percentage of counterfeit medicines within the worldwide pharmaceutical market. Their estimations reflect both the magnitude and the volatility of the problem: percentages of counterfeit medicines in different national pharmaceutical markets vary from as 1 percent to as high as 50 percent. In general, higher percentages refer to less developed countries and economies in transition whereas lower percentages refer to the developed countries. Therefore, it is essential to take into account geographical, economic, legal and social criteria in order to interpret these percentages (3).

Research has shown that counterfeit medicines is less spread in more developed countries due to a combination of enhanced legislation, stronger institutions and a more efficient regulatory control. According to the WHO, developed countries such USA, Australia, Canada, Japan, New Zealand and those within the European Union (EU) have a very low proportion of counterfeit medicines no more than one per cent of market value(5).

However, the fact that a considerable amount of counterfeit drugs cases are declared on an annual basis by developed countries proves that this problem still affects both developed and developing countries.

Nevertheless, the situation is more dramatic in less developed countries due to fragile economies, widespread poverty, lack of regulation, difficulties in controlling the system, as well as the difficulties in furthering and enforcing strong legislative measures. WHO has estimate shows that counterfeit medicines would represent approximately ten percent of the entire amount of medicines worldwide (5). Pfizer estimates that counterfeit Viagra alone causes a loss of 2 billion USD in sales. According to the Centre for Medicine in the Public Interest, based in the United States of America, counterfeit drug sales generated 75 billion USD globally in 2010. However, and according to other estimates, these rates increased to 20 per cent as there is a growing problem of drugs that look alike in most market. The situation seems to be even worse in some African countries.

There are no sufficient researches dedicated to understanding the problem of drug counterfeiting in developing countries including Nigeria especially from the consumers' perspective. There have been various published works on exploring, measuring or combating drug counterfeiting using various research design and making recommendations, while those efforts may, succeed in measuring or describing the prevalence of counterfeit drugs in developing countries, these studies fail to consider the factors contributing to the prevalence of these drugs from the consumer's perspective. Therefore, this study seeks to assess factors influencing the purchase of counterfeit drugs among consumers in rural community using the theory of planned behavior as the theoretical framework underpinning the research.

\section{Theoretical framework}

In other to understand why drug consumers engage in counterfeit drug purchase, Ajzen's (6) theoretical framework on planned behavior (TPB) was adopted and applied in this study.

According to TPB, behavioural actions can be predicted from an individual's intention and plan to carry out such behaviour under study. Ajzen proposes three categories of significant beliefs which include the behavioural beliefs, that is often expected to affect attitudes, the normative beliefs, that form the basic part of subjective norms and that of the control beliefs which offer the foundation for 
perceptions of behaviour control. The TPB advocates that the above mentioned beliefs will lead to the intent of an individual to act in a specific manner, although, the significance of the beliefs differs. Based on the findings from the TPB, it has been observed that the stronger the individual beliefs concerning the attitude, subjective norms and the perceived behaviour control, the more the prospect that such person will act in a specific or defined manner (7).

Intention represents the readiness and determination to carry out the behavior, and of the confidence, ability, and availability of indispensable opportunities and resources while behaviour is regarded as the function of intent to execute the behaviour (6). Therefore, the stronger the intention to execute an act or perceived behaviour control over the act, the higher the likelihood of performing a behaviour. According to Ajzen (1991) (6) variables such attitude, subjective norm, and perceived behavioural control are the constructive predictors of intention. Attitude in this context refers to an individual's emotional and evaluative deliberations about a behavior (8).

Emotive deliberation in this context reflects the extent to which an individual loves or disgusts a behavior. Evaluative deliberations can also be defined as a reflection of an individual's perception towards a behavior in relation to its benefits or harm. Based on the current study, it can be hypothetically said that the stronger the individual's attitude towards purchasing counterfeit drugs, the stronger the expectation for engagement into purchasing drugs (6)

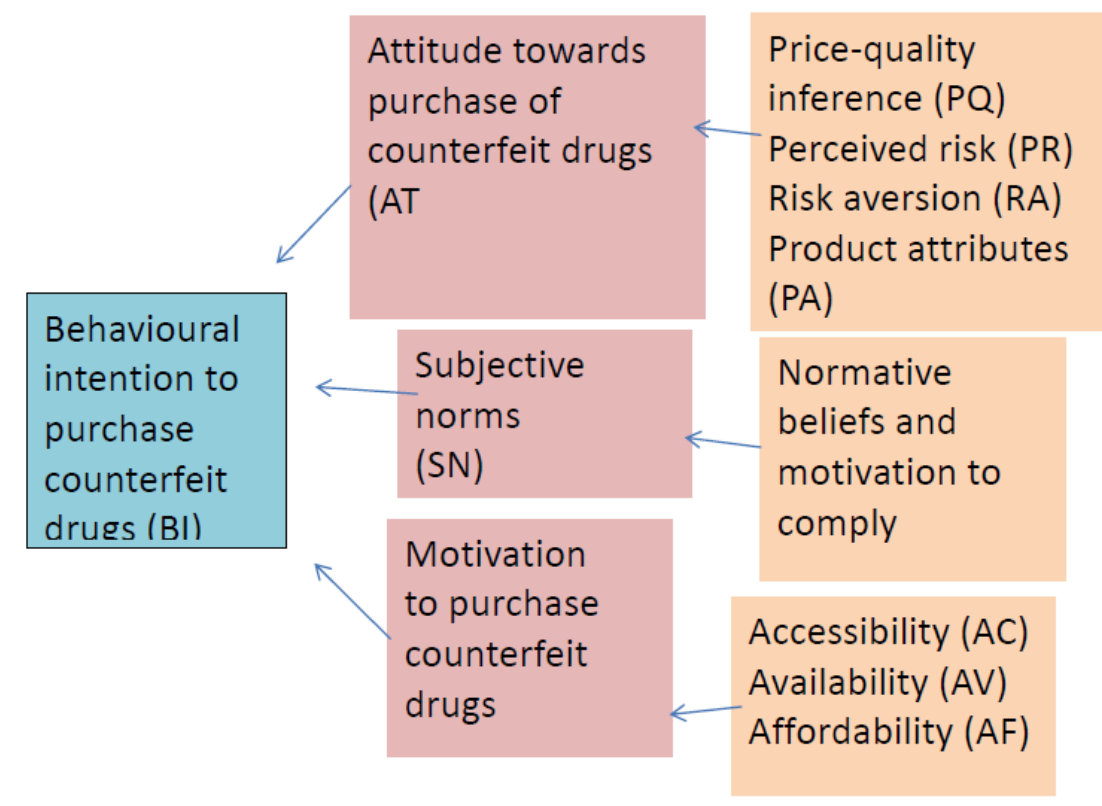

Conceptual framework explaining the theory of planned behavior with respect to the purchase of counterfeit drugs, adopted from Abubakr et al (2012)

\section{Methodology}

\section{Study location}

The study was conducted in Bekwarra Local Government Area. Bekwara is one of the 18 Local Government Areas in Cross River State, Nigeria with a population of 105,822 people existing in an area of $306 \mathrm{~km} 2$ (9). This local authority area is of historical significance to the Nigerian nation. It was in one of its towns, Gakem, that the first shot of the Nigerian Civil war (1967-1970) was fired (10). That war started the disintegration of values in Nigeria, spawning violence, hardships, poverty, hunger, drug abuse, family dysfunction and prostitution, which still rear their ugly heads today (11). Bekwarra indigenes are conservative traditional people with strict customs and values. 
Bekwarra Local Government Area is in the Northern Senatorial District of Cross River State. There are ten political wards in the local government as follows: Abuochiche, Afrike Ochagbe, Afrike Okpeche, Benten, Gakem, Abi-Aragin, Nyanya, Otukpuru, Otukpuru, Ugboro, Ukpah.

Bekwarra Local Government Area has it headquarters at Abuochiche. It is bounded in the north by Benue State, South by Ogoja Local Government Area, East by Obudu Local Government Area and West by Yala Government Area.

The major population groups of the local government area are Ujia, Unwapu, Unwagba Oli West, Oti East, Eya Aba, Beten, Uduo, Eya Adie, Ika-Ichia, Udomu, Atibulum, Afrike, Okpeche, Ikachor and Ochagbe. The major economic activities in the area include agriculture, cattle/goat and poultry rearing, petty trading et cetera. Majority of the indigenes are farmers whose produce and sold within and outside the state. The major traditional festival is the new yam festival held during the first week of September yearly and traditional market days are as includes Udama, Ugbada, Uchagu, Ugidi, Achanya (10)

\section{Study design}

This study is a community based cross-sectional descriptive study that employed the use of questionnaire to elicit information from respondents. The choice of the research design is because of it flexibility and adaptability to change. This design also requires strong focus and concern to create observational skills, capable of getting precise and accurate data and to be competent to interpret different situation effectively.

\section{Data collection tools}

A structure questionnaire was designed using the theory of planned behavior as a guide. The questionnaire contained information on the demographic characteristics of respondents, respondents perceived associated risk of counterfeit drugs, signs that are used to identify whether medication is counterfeit, questions that measured respondents' attitudes towards counterfeit drugs; subjective norm; factors that may motivate their purchase intention; and consumers purchase intention.

Five-point Likert scales were employed in questions that measured respondents' attitudes towards counterfeit drugs; subjective norm; factors that may motivate their purchase intention; and consumers purchase intention; with one representing 'strongly disagree' and five representing' strongly agree'.

\section{Sampling procedures}

Multi-stage sampling technique was employed in the selected of respondents as follows:

Stage I: collection of the list of all registered PMVs from the state ministry of health as sampling frame. This stage also included, mapping, enumeration of patent medicine vendor (PMVs) outlets.

Stage II: Simple random sampling technique was used to select 4 out of the 11 health patent medicine vendors (PMVs) distribution outlet in Bekwara Local government area. Using a list of all the PMVs, each was given a number (1-11), these numbers was written on a piece of paper which was folded, all the 11 papers were put in a container and vigorously shaken then 6 papers were picked from the container and the numbers recorded. PMVs with those numbers were then included in the study.

Stage 2: In each selected PMVs, systematic sampling technique was used to select drug end users (consumers), That is, research assistant was attached to each of the selected community PMVs to interview customers that check in to purchases drug. In order to avoid selection bias, the research assistant selected the first buyer and skip the second buyer, this continued systematically until the required sample size was achieved. Respondents that decline consent to be involved in the research was not included in the study.

\section{Data collection}

Four research assistants (2 males and 2 females) who are fluent in the local language and English will be recruited for data collection and were trained on field exercise and how to handle ethical 
issues. Those field assistant presented themselves as research assistant and follow the research protocol for obtaining data from respondents. Data were collected through one-on-one interview with consumers.

\section{Method of analysis data analysis}

The collected data was entered in excel environment and screened to fulfill the requirement for running analysis and then exported to statistical package for social science (SPSS) version 22.0 for analysis. Descriptive analysis was computed for the demographics to have a thorough description of the demographic characteristics of the respondents. Finally, the inferential statistics were carried out to reach conclusions on the findings to either reject or fail to reject the hypothesis of the research. Level of significance for this study stands at 0.05 .

\section{Test for reliability and validity of instrument}

To ensure the validity and reliability of the constructs, a pilot study was conducted using a different population with similar characteristics with that of the study population. At the end of the pilot study, collected data were entered into SPSS version 20.0 and analyzed. The Cronbach coefficient Alpha was computed to measure the internal consistency of the instrument (12). Cronbach Alpha refers to a reliability coefficient that specifies the degree to which items are correlated positively to one another, the nearer the Cronbach alpha to 1 , the better the internal consistency (13). The entire Cronbach Alpha coefficient for this study is above 0.70 thus, indicating a good internal consistency for the variables under study (Table 6.0).

\section{Ethical consideration}

Permission was granted from Cross River State Health research ethics committee to carry out the research in the state. During field work, information sheets about the study in Bekwara were given out to the respondents, explaining why the research was carried out, by whom, and what it would involve. Participants were allowed to withdraw from interview at any time he or she want.

Confidentiality of all study participants was assured. Everybody was informed that no names or direct identification made to the questionnaire except numerical identification number was used for follow up. Before interview, study respondents were requested to participate voluntarily. Respondents were also told of the benefits they will derive from participating in the study.

\section{Results}

\section{Socio-demographic characteristics}

A total of 250 questionnaires were distributed and 236 questionnaires were filled and returned, resulting to a response rate of $94.4 \%$. The mean age for the collected samples was $30.51(\mathrm{SD}=11.46)$.

Findings from this study shows that 139(58.9\%) of the respondents were males, while $97(41.1 \%)$ were females. Majority of the respondents $127(53.8 \%)$ were single, 99(41.9\%) were married while 10(4.2\%). Findings from this study also shows that a higher percentage of the respondents (97\%) were Christians, 3(1.3\%) were Muslims, 3(1.3\%) practice African traditional religion and only $1(0.4 \%)$ of the respondents practice other religion not mentioned. Majority of the respondents 135(57.2) had secondary school education, 51(21.6\%) had university education, 33(14\%) had primary education while 17(7.2\%) had no formal education (table 1.0).

\section{Means of identification of counterfeit drugs by consumers}

Respondents reported the following frequently used means of identification of counterfeit drugs: a strange smell; 36(15\%), a strange taste or colour; 30(12.7\%), drug breaking apart very easily or be cracked or chipped; 22(9.3\%), labels that have directions that seem incorrect including NAFDAC number and manufacturers address; 32(13.6\%), cost very little, especially compared with the normal price of that particular drug;56(23.7\%) (Table 2.0) 


\section{Perceived associated risk of counterfeit drugs by consumers}

Findings from this study shows that respondents perceived the following as associated risk of counterfeit drugs: unexpected side effects 33(14\%), allergic reactions 38(16.1\%), worsening of their medical Condition 48(20.3\%), death 46(19.5\%) and overdose 19(8.1\%). Respondents sources of information on the perceived risk of counterfeit drugs shows that majority of the respondents, 102(43.2\%) got it from health professionals 54(22.9\%) from Government, 36(15.3\%) from nongovernmental organization, $16(6.8 \%)$ got it from manufacturers, while $28(11.9 \%)$ got it from other sources not mentioned (Table 3.0)

\section{Predicting behavioural intention to purchase counterfeit drugs}

Findings from this study showed a correlation between study variables. Behavioural intention was correlated with attitude $(\mathrm{R}=0.64)$. Subjective norms were associated with behavioural intention $(\mathrm{R}=0.65)$ but was not significant at 0.005 . There was also an observed significant relationship between behavioural intentions and motivation $(\mathrm{R}=0.52)$ (table 7.0)

\section{Confirmatory factor analysis}

One of the requirement to carry out factor analysis is for the data to pass Kaiser-Meyer-Olkin KMO and Bartlett's test, the bench mark usually 0.6 and above $(12,13)$. This study met the criteria with a KMO score above 0.62 and a significant Bartlett's Test, which indicate that factor analysis can be carried out in the collected data (table 5.0)

Table1.0 Socio-demographic characteristics

\begin{tabular}{|c|c|c|}
\hline Variable & Frequency & Percent \\
\hline \multicolumn{3}{|l|}{ Sex } \\
\hline Male & 139 & 58.9 \\
\hline Female & 97 & 41.1 \\
\hline Total & 226 & 100.0 \\
\hline \multicolumn{3}{|l|}{ Marital status } \\
\hline Single & 127 & 53.8 \\
\hline Married & 99 & 41.9 \\
\hline Divorced & 10 & 4.2 \\
\hline Total & 236 & 100.0 \\
\hline \multicolumn{3}{|l|}{ Religion } \\
\hline Christian & 232 & 97.1 \\
\hline Muslim & 3 & 1.3 \\
\hline $\begin{array}{l}\text { Traditional African } \\
\text { Religion }\end{array}$ & 3 & 1.3 \\
\hline Others & 1 & .4 \\
\hline Total & 236 & 100 \\
\hline \multicolumn{3}{|l|}{ Level of education } \\
\hline University & 51 & 21.6 \\
\hline Secondary School & 135 & 57.2 \\
\hline Primary school & 33 & 14.0 \\
\hline $\begin{array}{ll}\text { No } & \text { formal } \\
\text { education } & \end{array}$ & 17 & 7.2 \\
\hline Total & 236 & 100 \\
\hline
\end{tabular}




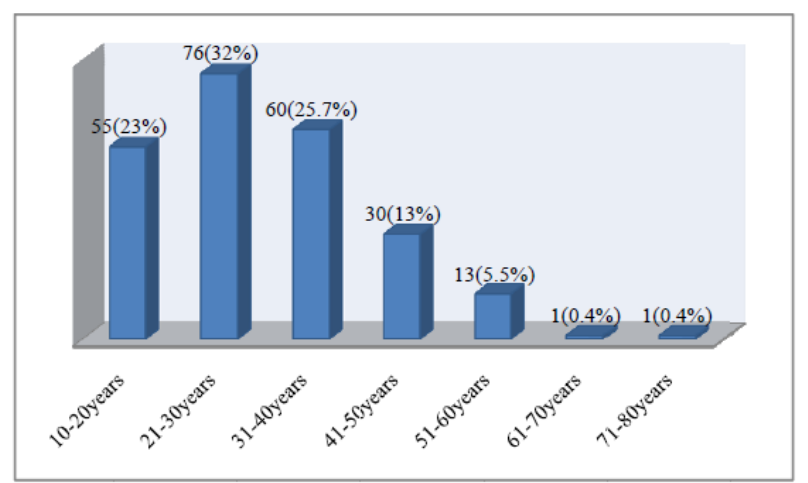

Fig 1.0 Age distribution of respondents

Table 2.0 Means of identification of counterfeit drugs by consumers

\begin{tabular}{|l|c|c|c|c|c|c|}
\hline \multicolumn{1}{|c|}{ Variable } & $\begin{array}{c}\text { Never } \\
\text { used }\end{array}$ & $\begin{array}{c}\text { Rarely } \\
\text { used }\end{array}$ & $\begin{array}{c}\text { Occasionally } \\
\text { used }\end{array}$ & $\begin{array}{c}\text { Frequently } \\
\text { used }\end{array}$ & $\begin{array}{c}\text { Most } \\
\text { frequently } \\
\text { used }\end{array}$ & Total \\
\hline A strange smell & $\mathbf{1 1 9}$ & $\mathbf{2 8}$ & $\mathbf{4 6}$ & $\mathbf{3 6}$ & $\mathbf{7}$ & 236 \\
\hline A strange taste or colour & $\mathbf{1 0 4}$ & 37 & 58 & 30 & 7 & 236 \\
\hline $\begin{array}{l}\text { Drug breaking apart } \\
\text { very easily or be cracked } \\
\text { or chipped }\end{array}$ & $\mathbf{9 5}$ & 34 & 69 & 22 & 16 & 236 \\
\hline $\begin{array}{l}\text { Labels that have } \\
\text { directions that seem } \\
\text { Incorrect including } \\
\begin{array}{l}\text { NAFDAC number and } \\
\text { manufacturers address }\end{array}\end{array}$ & $\mathbf{1 0 8}$ & 27 & 42 & 32 & 27 & 236 \\
\hline $\begin{array}{l}\text { Cost very little, } \\
\text { Especially compared } \\
\text { with the normal price of } \\
\text { that particular drug }\end{array}$ & $\mathbf{6 7}$ & $\mathbf{3 0}$ & $\mathbf{6 7}$ & $\mathbf{5 6}$ & $\mathbf{1 6}$ & $\mathbf{2 3 6}$ \\
\hline
\end{tabular}

Table 3.0 Perceived associated risk of counterfeit drugs

\begin{tabular}{|l|c|c|}
\hline \multicolumn{1}{|c|}{ Variable } & Frequency & Percentage \\
\hline Unexpected side effects & 33 & 14.0 \\
\hline Allergic reactions & 38 & 16.1 \\
\hline $\begin{array}{l}\text { Worsening of their medical } \\
\text { Condition }\end{array}$ & 48 & 20.3 \\
\hline Death & 46 & 19.5 \\
\hline Overdose & 19 & 8.1 \\
\hline Vomiting & 11 & 4.7 \\
\hline General illness & 19 & 8.1 \\
\hline I don't know & 22 & 9.3 \\
\hline Total & 236 & 100.0 \\
\hline
\end{tabular}




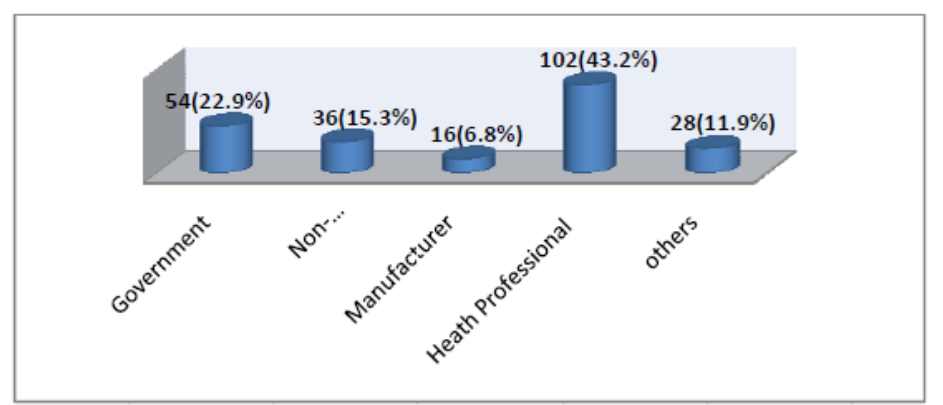

Fig 2.0 Sources of information on the associated risk of counterfeit drugs

Table 4.0 Component loadings for measurement model

\begin{tabular}{|c|c|}
\hline Variable & Loadings... \\
\hline \multicolumn{2}{|l|}{ Perceived product attributes (PA) } \\
\hline $\begin{array}{l}\text { Authentic drugs are often of better quality than non-authentic } \\
\text { drugs }\end{array}$ & 0.225 \\
\hline Non-authentic drugs are just as good as authentic drugs & -0.135 \\
\hline Purchasing non-authentic drugs is worthless & 0.646 \\
\hline Non-authentic drugs are not worth buying & 0.617 \\
\hline Authentic drugs perform much better than non-authentic & 0.403 \\
\hline Authentic drugs are more reliable than non-authentic & 0.188 \\
\hline Authentic drugs are worth the money they cost & 0.350 \\
\hline $\begin{array}{l}\text { Overall, my cognitive belief regarding the attributes of non- } \\
\text { authentic drugs is negative }\end{array}$ & 0.552 \\
\hline \multicolumn{2}{|l|}{ Perceived risks (PR) } \\
\hline The risk that I take when I buy a non-authentic drug is high & 0.584 \\
\hline $\begin{array}{l}\text { There is high probability that the non-authentic drug doesn't } \\
\text { work }\end{array}$ & 0.492 \\
\hline Spending money on non-authentic drugs might be a bad decision & 0.656 \\
\hline Generally speaking, non-authentic drugs can be very dangerous & 0.456 \\
\hline Purchasing non authentic drugs is quite risky & 0.466 \\
\hline \multicolumn{2}{|l|}{ Risk aversion (RA) } \\
\hline When I buy something, I prefer not taking risks & 0.154 \\
\hline I like to be sure the product is good one before buying it & 0.341 \\
\hline I don't like to feel uncertainty when I buy something & 0.292 \\
\hline I always avoid risky things & 0.194 \\
\hline \multicolumn{2}{|l|}{ Price-quality inference (PQ) } \\
\hline $\begin{array}{l}\text { Generally speaking, the higher the price of a drug, the higher the } \\
\text { quality }\end{array}$ & 0.151 \\
\hline You have always to pay a bit more for the best & 0.408 \\
\hline The price of a drug is a good indicator of its quality & 0.254 \\
\hline $\begin{array}{l}\text { The price premium of authentic drugs compare to non-authentic } \\
\text { is mostly justified }\end{array}$ & 0.297 \\
\hline \multicolumn{2}{|l|}{ Awareness of societal consequences (ASC) } \\
\hline $\begin{array}{l}\text { Purchasing non-authentic drugs harms the economy of my } \\
\text { country through loss of taxation revenue }\end{array}$ & 0.245 \\
\hline $\begin{array}{l}\text { Purchasing non-authentic drugs undermines the national health- } \\
\text { care system of my country }\end{array}$ & 0.201 \\
\hline Purchasing non-authentic drugs discourages manufacturers of & 0.341 \\
\hline
\end{tabular}




\begin{tabular}{|c|c|}
\hline \multicolumn{2}{|l|}{$\begin{array}{l}\text { legitimate drugs from investment in research and development } \\
\text { and hence slows the development of new effective drugs }\end{array}$} \\
\hline Subjective norm (SN) & \\
\hline $\begin{array}{l}\text { My relatives and friends approve my decision to buy non- } \\
\text { authentic drugs }\end{array}$ & -0.409 \\
\hline $\begin{array}{l}\text { My relative and friends think that I should buy non-authentic } \\
\text { drugs }\end{array}$ & -0.480 \\
\hline \multicolumn{2}{|l|}{ Affordability (AF) } \\
\hline $\begin{array}{l}\text { Generally speaking, one of the reasons for buying non-authentic } \\
\text { drugs is that the prices of authentic drugs are unaffordable }\end{array}$ & 0.002 \\
\hline $\begin{array}{l}\text { Generally speaking, one of the reasons for buying non-authentic } \\
\text { drugs is that it has affordable prices }\end{array}$ & 0.304 \\
\hline $\begin{array}{l}\text { One of the reasons for buying non-authentic drugs is that I would } \\
\text { not be ready to pay the price of the authentic drugs although I } \\
\text { prefer them }\end{array}$ & 0.611 \\
\hline $\begin{array}{l}\text { Generally speaking, one of the reasons for buying non-authentic } \\
\text { drugs is that the authentic drugs are not always available }\end{array}$ & 0.606 \\
\hline $\begin{array}{l}\text { Unaffordable prices of authentic drugs may cause me to buy } \\
\text { non-authentic drugs }\end{array}$ & 0.646 \\
\hline \multicolumn{2}{|l|}{ Availability (AV) } \\
\hline $\begin{array}{l}\text { Generally speaking, one of the reasons for buying non-authentic } \\
\text { drugs is that the authentic are not always available }\end{array}$ & 0.477 \\
\hline $\begin{array}{l}\text { Non-availability of authentic drugs may cause me to buy non- } \\
\text { authentic drugs }\end{array}$ & 0.613 \\
\hline \multicolumn{2}{|l|}{ Accessibility (AC) } \\
\hline $\begin{array}{l}\text { Generally speaking, one of the reasons for buying non-authentic } \\
\text { drugs is that the authentic drugs are not always accessible }\end{array}$ & 0.622 \\
\hline $\begin{array}{l}\text { For me, purchasing a non-authentic drug would not be an option } \\
\text { even if the authentic }\end{array}$ & 0.449 \\
\hline $\begin{array}{l}\text { Non-accessibility of authentic drugs may cause me to buy non- } \\
\text { authentic }\end{array}$ & 0.607 \\
\hline \multicolumn{2}{|l|}{ Behavioural intention (BI) } \\
\hline It is likely that I may buy a non-authentic drug in the future & 0.532 \\
\hline $\begin{array}{l}\text { Still there is a chance that I say favorable things about non- } \\
\text { authentic drugs }\end{array}$ & 0.499 \\
\hline
\end{tabular}

Table 5.0 KMO and Bartlett's Test

\begin{tabular}{|c|c|c|}
\hline \multicolumn{3}{|c|}{ KMO and Bartlett's Test } \\
\hline $\begin{array}{c}\text { Kaiser-Meyer-Olkin Measure of } \\
\text { Sampling Adequacy. }\end{array}$ & .621 \\
\hline $\begin{array}{c}\text { Bartlett's Test of } \\
\text { Sphericity }\end{array}$ & $\begin{array}{c}\text { Approx. Chi- } \\
\text { Square }\end{array}$ & 2053.043 \\
\cline { 2 - 3 } & Df & 666 \\
\cline { 2 - 3 } & Sig. & .000 \\
\hline
\end{tabular}


Table 6.0 Composite reliability

\begin{tabular}{|l|c|}
\hline \multicolumn{1}{|c|}{ Variables } & Cronbach coefficient Alpha \\
\hline Perceived product attributes (PA) & 0.92 \\
\hline Perceived risks (PR) & 0.74 \\
\hline Risk aversion (RA) & 0.93 \\
\hline Price-quality inference (PQ) & 0.81 \\
\hline Awareness of societal consequences (ASC) & 0.77 \\
\hline Subjective norm (SN) & 0.71 \\
\hline Affordability (AF) & 0.90 \\
\hline Availability (AV) & 0.83 \\
\hline Accessibility (AC) & 0.91 \\
\hline Behavioural intention (BI) & 0.90 \\
\hline
\end{tabular}

Table 7.0 Relationship between Behavioural intention and Attitude, subjective norms and motivation

\begin{tabular}{|c|c|c|}
\hline & \multicolumn{2}{|c|}{ BI } \\
\hline & Pearsons ${ }^{\circledR}$ & Sig \\
\hline Attitude (ATT) & $0.64 *$ & 0.133 \\
\hline Subjective norms (SN) & 0.65 & 0.001 \\
\hline Motivation (MT) & $0.52^{*}$ & 0.197 \\
\hline
\end{tabular}

*correlation significant at 0.05

\section{Discussions}

Despite available strategies to control or combat the influx of counterfeit drugs in Nigeria, there is still high proliferation of counterfeit drugs in the Nigeria market (14). Most counterfeit drugs look like genuine version of drug which makes it difficult for consumers to distinguish counterfeit drugs from the original ones.

Findings from this study shows that respondents identify counterfeit based on strange smell; 36(15\%), strange taste or colour; 30(12.7\%), drug breaking apart very easily or be cracked or chipped; 22(9.3\%), Labels that have directions that seem incorrect including NAFDAC number and manufacturers address; 32(13.6\%), Cost very little especially compared with the normal price of that particular drug; 56(23.7\%). This is contrary to the findings of Odili, Osemwenkha, Eke and Okeri Henry (2006) (19)

Respondent's ability to identify counterfeit drugs qualitatively based on packaging, labelling, and appearance/colour are an important step towards creating suspicion and discouraging the illicit trade in counterfeit drugs for malaria and other conditions (14)

Unfortunately, one of the major means to confirm whether a drug is counterfeit is by performing a chemical analysis in a laboratory which is quite expensive but however, physical checks such as the colour of the drugs, the odour/taste of, expiry dates and batch numbers on the box not matching those of the drugs inside, and patient's information leaflets being in the wrong language or out of date may indicate whether a drug/product is counterfeited (14).

The level of awareness of respondents on these signs is important towards suspicion of counterfeit drugs and avoidance of buying such drugs consequently reducing the market and profit of these counterfeit drugs (19).

Another aim of this study was to assess those factors that influence consumers to purchase counterfeit drugs using the theory of planned behavior framework as a guide.

Several researchers have been carried out using the theory of planned behavior to predict intention to perform a defined or various kinds of behaviour including health related behaviours. Findings from this study have shown that the theory of the planned behavior model can be used to explained human behavioural including intensions to carry out various kinds of behaviours including intention to 
purchase counterfeit drugs. Variables such as Attitude, societal norms and motivation were significant predictors of intention to purchase counterfeit drugs.

The present study showed a positive correlation between Attitude of respondents and behavioural intention, Attitude was found to be a major predictor of behavioural intention which was similar to a study carried out by Bisonette and Contento (2001) (15). Also a study carried out by Abubakar et. al (2012) indicated a strong relationship between behavioral attitude and behavioural intention in a (16).

Findings from this study shows a correlation between subjective norms and the intention of respondents to purchase counterfeit drugs but the relation was not significant at $0.005 \mathrm{p}$-value although people tend to be guided by personal norms rather than subjective norms in most situations as the former are more outstanding than the latter (17), this is consistent with other research that has suggested subjective norm to be the weakest predictor of intention in the theory of planned behavior, this study found subjective norms not to be a significant predictor of intention.

The above findings also contradict findings from a study carried out by Mullan and Wong (2009) (18), which reported social normative influences than attitudes. Thus, the decision to purchase counterfeit drugs was mainly determined by what they perceived rather than by the influence of other people or the resources or opportunities they perceived the operation to possess.

\section{Limitations of the study}

Limitations of a study are meant to guide future research. This study had the following limitations which should be addressed in future research. One of its limitations is that of limited sample to test hypothesis. Therefore, there is need to carry out further research in the study area using a larger sample size. Another limitation of this study is that of selection bias as most drug consumers may likely not be selected if they happen not to buy drugs the day questionnaire was collected as research assistants were attached only PMVs outlets. The TPB is a very useful model which can be applied in other settings other than the study area

\section{Conclusion/recommendation}

The involvement of consumers in the community in the fight against counterfeit drugs is often neglected. Drug consumers mainly use cost of drugs as a means of identification of counterfeit drugs. Consumers behavior, intention and attitude towards counterfeit drugs are correlated. The present study establishes a need to empower consumers in the community through awareness and educational interventions to enable them identify counterfeit in the community and report to the appropriate authority.

\section{References}

[1] Akunyili, D.N., 2007. Couterfeiting medicines: A serious crime against humanity. Proceedings of the Directora General of the National Agency for Food and Drug Administration and Control (Nafdac), April 10, 2007, Nigeria to the European Parliament in Brussels, pp: 1-7.

[2] Ajzen I. (1991). The Theory of planned behavior. Organizational Behavior and Human Decision Processes.;50:179-211

[3] Akpan N.U. (1972). The struggle for secession, 1966-70: Personal Account of the Nigerian Civil War. ISBN-10: 0714629499. Frank Cass Publishers, London.

[4] Ajayi J.O. (2003). The HIV/AIDS Epidemic in Nigeria: Some Ethical Considerations. ISBN 88- 7652955-1. Gregorian University Press, Rome Italy

[5] Abubakr A. Alfadl, Mohamed Izham M. Ibrahim and Mohamed A. Hassali (2012). Consumer behaviour towards counterfeit drugs in adeveloping country. Journal of pharmaceutical health service.

DOI 10.1111/j.1759-8893.2012.00095.x ISSN 1759-8885

https://www.researchgate.net/publication/259648430

[6] Bisonette, M. M. \& Contento, I. R. (2001). Adolescents' perspectives and food choice behaviours in terms of the environmental impacts of food production practices: application of a psychosocial mode. Journal of Nutrition Education, 33(2), 72-82. 
[7] Charles Clift (2010). Combating counterfeit, falsified and substandard medicines: defining the way forward? centre on global health security, ghbp 2010/01

[8] Engle, R.L., Dimitriadi, N., Gavidia, J.V., Schlaegel, C., Delanoe, S., Alvarado, I., He, X., Buame, S. and Wolff, B. (2010). “Entrepreneurial intent: a twelve-country evaluation of Ajzen's model of planned behavior”, International Journal of Entrepreneurial Behavior \& Research, Vol. 16 (1), pp. 35-57. Emerald Group Publishing Limited. 1355-2554 DOI 10.1108/13552551011020063.

[9] Liñán, F., and Chen, Y. (2009). Development and cross-cultural application of a specific instrument to measure entrepreneurial intentions. Entrepreneurship Theory \& Practice, 5, 593-617.

[10] Mhando Linus, Jande Mary, Anthony Liwa, Mwita Stanley, \& Marwa Karol (2016). Public Awareness and Identification of Counterfeit Drugs in Tanzania: A View on Antimalarial Drugs.

[11] Mullan, B.A. \& Wong, C.L. (2009). Hygienic food handling behaviors. An application of the Theory of Planned Behaviour. Appetite, 52, 757-761.

[12] National Bureau of Statistics (2006). Federal republic of Nigeria 2006 population census. www.nigerianstat.gov.ng/

[13] Newton PN, Lee SJ, Goodman C, Fernández FM, Yeung S, Phanouvong S, Kaur H, Amin A, Whitty C, Kokwao G, Lindegardh N, Lukulay P, White L, Day N, Green M, White N (2009) Guidelines for field surveys of the quality of medicines: a proposal. PLoS Med 6

[14] Odili, Valentine U., Osemwenkha Sylvia, Eke Esther U. and Okeri Henry A (2006). Identification of Counterfeit Drugs by Community Pharmacists in Lagos State. Tropical Journal of Pharmaceutical Research, 5(1), pp. 545-550

[15] Thogersen, J. (2009). The motivational roots of norms for environmentally responsible behavior. Basic and Applied Social Psychology, 31, 348-362. http://www.textcheck.com/certificate/FKgpLo

[16] Sandhu, M. S., Sidique, F. S., and Riaz, S. (2011). Entrepreneurship barriers and entrepreneurial inclination among Malaysian postgraduate students. International Journal of Entrepreneurial Behaviour \& Research Vol. 17 No. 4, 2011 pp. 428-449 Emerald Group Publishing Limited 1355-2554

[17] Sekaran, U. (2003). Research Methods for Business: A Skill-Building Approach. John Wiley \& Sons, New York, NY.

[18] World Health Organization. Substandard and counterfeit medicines. Fact sheet No. 275, 2012. Available at http://www.who.int/mediacentre/factsheets/2012/fs275/en/ (last accessed 14, September 2016).

[19] Yankus W (2006). Counterfeit Drugs: Coming to a Pharmacy Near You. American Council on Science and Health. Available: www.acsh.org/publications/pubID.1379/pub_detail.asp 